УДК 343.24

DOI: 10.21779/2500-1930-2018-33-3-112-117

\title{
Д.Б. Лапmев
}

\section{К вопросу об иерархии мер уголовно-правового воздействия}

Западно-Сибирский филиал Российского государственного университета правосудия; Россия, 634050, г. Томск, пл. Ленина, 2; Lapa612@таil.ru

Статья посвящена вопросам иерархии мер уголовно-правового воздействия. Раскрывается «процессуальный» подход к определению уголовно-правового воздействия, а также его материально-правовой аспект, включающий перечень мер, с помощью которых уголовноправовая политика формирует направления коррекции преступного поведения. Обосновывается необходимость вывода за пределы структуры уголовно-правового воздействия освобождения от уголовной ответственности и от наказания. Соотносятся категории «уголовно-правовое воздействие» и «уголовная ответственность». Делается вывод, согласно которому «уголовная ответственность» является близкой по смыслу, но более широкой по содержанию, охватывающей в том числе совокупность дополнительных ограничений, применяющихся к лицу в период, когда основное правоотношение, связанное с принуждением лица к обязанности понести негативные последствия в связи с совершенным преступлением, уже завершилось. Предлагается подход к определению иерархии мер уголовно-правового воздействия, в котором получает отражение его предмет, правоограничительная сущность, рациональная экономия мер государственного принуждения: две относительно самостоятельные, взаимопроникающие подсистемы (наказание и иные меры уголовно-правового характера), внутри которых выстаиваются отдельные соподчиненные элементы.

Ключевые слова: уголовно-правовое воздействие, уголовная ответственность, наказание, иные меры уголовно-правового характера, иерархия мер уголовно-правового воздействия.

В современный период юридический инструментарий воздействия на лиц, совершивших общественно опасные деяния, приобрел многоспектральный характер. Научное осмысление получили его системные [1, с. 66], философские [2, с. 149], аксиологические [3, с. 73] и методологические [4, с. 70] основы. Взаимное соподчинение и соотношение отдельных элементов внутри этого инструментария было обосновано в трудах российских ученых в конце XIX - начале XX в. (например, С.В. Познышевым [5, с. 100], Н.С. Таганцевым [6, с. 465]).

Однако процесс познания осложняется тем, что терминологическое содержание категории «уголовно-правовое воздействие» не раскрывается в нормах уголовного закона, вследствие чего ее доктринальное толкование становится достаточно важным как в целях уяснения ее правовой природы, так и для обоснования определенных иерархических связей в структуре юридических последствий совершения преступления.

Нормативно уголовно-правовое воздействие реализуется в двух блоках правоотношений (наказание или иные меры уголовно-правового характера), и, как представляется, приоритет приобретает тот из них, который в наибольшей степени позволяет минимизировать вредные последствия противоправного поведения.

Определение наказания закреплено в ч. 1 ст. 43 УК РФ, тогда как иные меры уголовно-правового характера законодатель не счел необходимым «оснастить» юридической дефиницией. В ч. 1 ст. 68 УК РФ применительно к наказанию используется кате- 
гория «исправительное воздействие»; в статьях 90-91 УК РФ категория «воспитательное воздействие» служит характеристикой одной из иных мер уголовно-правового характера. Как видно, нормотворческий терминологический дисбаланс все же позволяет объединить в содержании дефиниции «меры уголовно-правового воздействия» обе названные позиции, а в механизме применения уголовно-правового воздействия - выделить два вышеуказанных самостоятельных блока правоотношений.

Применительно к содержанию категории «уголовно-правовое воздействие» в правовой доктрине сформировано несколько подходов. Сторонники одного из них раскрывают данное понятие через определение направлений специальной деятельности государства и его уполномоченных органов по регулированию тех общественных отношений, которые возникают в связи с нарушением уголовно-правового запрета [7, с. 28].

С долей условности эту позицию можно назвать «процессуальной», основанной на лексическом значении слова «воздействие» (влияние, понуждение, способ изменения [8, с. 78], то есть некий процесс, в ходе которого достигается преобразование объекта воздействия: в данном случае поведения лица, совершившего общественно опасное посягательство).

Второй подход, напротив, тяготеет к материально-правовому аспекту уголовноправового воздействия и включает перечень мер (форм реализации уголовной ответственности), с помощью которых уголовно-правовая политика формирует направления коррекции преступного поведения. Интенсивность и характер этих мер зависят от общественной опасности содеянного и личности виновного [9; 10]. Соответственно в результате нормотворческого процесса данные меры получают правовую основу для реализации и могут применяться к лицам, совершившим общественно опасные посягательства.

В развитие двух названных научных течений некоторые авторы определяют уголовно-правовое воздействие как систему правовых мер, закрепленных в уголовном законе и необходимых для эффективной охраны личности, общества и государства от преступных посягательств [11, с. 56].

В систему мер уголовно-правового воздействия ученые включают уголовное наказание, условное осуждение, освобождение от уголовной ответственности и от наказания, иные меры уголовно-правового характера (а также особые положения закона, характеризующие уголовную ответственность несовершеннолетних, судимость и некоторые другие рядоположенные институты) [12, с. 10]. В данном случае акцент делается именно на мерах, которые могут применяться в целях коррекции преступного поведения и на принципах выбора этих мер.

Полагаем, что для выстраивания иерархии мер уголовно-правового воздействия более целесообразным будет использовать последний из приведенных подходов.

Мерами уголовно-правового воздействия являются предусмотренные уголовным законом виды наказаний и альтернативные им уголовно-правовые средства (иные меры уголовно-правового характера).

Надо отметить, что учеными выстроена иерархия мер юридической ответственности, в структуру которой достаточно гармонично включена система уголовных наказаний [13, с. 40]. Так, предложена характеристика общества как сложной социальной системы, частью которой закономерно становятся юридическая ответственность и наказание. Можно согласиться и с тем, что гносеологический потенциал исследования уголовной ответственности в системе социальных мер воздействия на лиц с девиантным (отклоняющимся) поведением достаточно высок [14, с. 309]. Однако система иных мер уголовно-правового характера, в отличие от системы наказаний в действующем зако- 
нодательстве, отсутствует [15, с. 44]. Более того, отождествление уголовной ответственности с наказанием и иными мерами уголовно-правового характера, широко представленное на страницах юридической печати [16; 17], представляется некорректным, поскольку, в частности, иные меры уголовно-правового характера могут применяться при освобождении лица от уголовной ответственности (судебный штраф). В связи с этим логично прибегнуть к другому способу построения иерархии мер уголовноправового воздействия.

Таким способом, на наш взгляд, является моделирование, в основе которого лежит определенная аналогия, воспроизводящая функциональные связи предмета исследования (оригинала) [18, с. 12].

В рассматриваемом случае «оригиналом» выступает уголовно-правовое воздействие как совокупность возможных мер, применяющихся в связи с опасным поведением лиц, посягающих на нормальный порядок осуществления общественных отношений.

В структуре воздействия мы выделяем наказание и иные меры уголовноправового характера, а за ее пределы выводим освобождение от уголовной ответственности и от наказания. Категория «уголовная ответственность» в данном случае представляется близкой по смыслу, но более широкой по содержанию, охватывающей последний дистанцированный нами элемент, а также с учетом положений ст. 86 УК РФ и норм Федерального закона «Об административном надзоре за лицами, освобожденными из мест лишения свободы» [19] - совокупность дополнительных ограничений, применяющихся к лицу в период, когда основное правоотношение, связанное с принуждением лица к обязанности понести негативные последствия в связи с совершенным преступлением, уже завершилось.

В результате получаем две относительно самостоятельные, взаимопроникающие подсистемы (наказание и иные меры уголовно-правового характера), внутри которых могут быть выстроены отдельные соподчиненные элементы.

Наказания, в свою очередь, можно разделить на реально исполняемые и назначаемые условно (или с отсрочкой исполнения). Реально исполняемые наказания подразделяются на основные (связанные с изоляцией от общества либо не связанные) и дополнительные (имущественные либо неимущественные). Иные меры уголовно-правового характера можно дифференцировать на испытательные, воспитательные, имущественные и лечебные.

Основаниями для выстраивания представленной иерархии являются:

- предмет и способ воздействия, заключающиеся в направлениях коррекции противоправного поведения;

- интенсивность принуждения, применяемого к лицу, совершившему общественно опасное деяние;

- характер и пределы воздействия, определяющиеся видом правоограничений.

Из представленной иерархии мер уголовно-правового воздействия видно, что наказание является структурно более сложной подсистемой, элементы которой расположены в зависимости от строгости (как это и предусмотрено в ст. 44 УК РФ), а также в зависимости от природы возлагаемых на субъекта ограничений. В свою очередь, иные меры уголовно-правового характера выступают частью (подсистемой) уголовноправового воздействия, выстроенной в зависимости от сущности направлений коррекции общественно опасного поведения.

В предложенной структуре мер уголовно-правового воздействия получают отражение его предмет, правоограничительная сущность, рациональная экономия мер государственного принуждения. 


\section{Литература}

1. Подройкина И.А. Теоретические основы построения системы наказаний в уголовном законодательстве России: дис. ... докт. юрид. н.: 12.00.08. - Омск, 2017. C. 66-110.

2. Милюков С.Ф. Российское уголовное законодательство: опыт критического анализа. - СПб.: Знание, 2000. - С. 149-173.

3. Бочкарев C.A. Аксиология уголовного права: введение в тему и проблемы ее становления // Российский журнал правовых исследований. - 2015. - № 4. - С. 73-80.

4. Дядькин Д.С. Теоретические основы назначения уголовного наказания. СПб.: Юридический центр Пресс, 2006. - С. 70-121.

5. Таганщев Н.С. Русское уголовное право: Лекции. Часть общая. - М.: Наука, 1994. - C. 100-102.

6. Познышев С.В. Основные начала науки уголовного права. - М.: Спарк, 1999. C. 465-467.

7. Дуюнов В.К. Уголовно-правовое воздействие: теория и практика. - М.: Норма, 2003. - C. 28.

8. Лопатин В.В., Лопатина Л.Е. Русский толковый словарь - М.: Эксмо, 2007. C. 78 .

9. Лопашенко Н.А. Основы уголовно-правового воздействия: уголовное право, уголовный закон, уголовно-правовая политика. - СПб.: Юридический центр пресс, 2004. - С. 7.

10. Сабитов T.P. Уголовно-правовая политика Российской Федерации и ее принципы // Вестник НГУ. Сер. «Право». - 2007. - Т. 3, вып. 1. - С. 167-175.

11. Воронин В.Н. Индивидуализация наказания: монография. - М.: Проспект, 2017. - C. 56-60.

12. Бавсун М.В. Уголовно-правовое воздействие: идеология, цели и средства реализации: дис. ... докт. юрид. н.: 12.00.08. - Омск, 2013. - С. 10-11.

13. Подройкина И.А., Улезько С.И. Система уголовных наказаний в иерархии мер юридической ответственности // Вестник Краснодарского университета МВД России. 2016. - № 2. - C. 40-44.

14. Гареев М.Ф. Законодательная регламентация мер уголовно-правового воздействия - уяснение сущности уголовной ответственности // Вестник ТИСБИ. - 2011. № 3. - С. 309-317.

15. Акутаев Р.М. Понятие и система иных мер уголовно-правового характера, их отличие от наказания // Российская юстиция. - 2014. - № 4. - С. 44-48.

16. Бриллиантов A.B. Освобождение от уголовной ответственности с учетом обобщения судебной практики: научно-практ. пособие. - М.: Проспект, 2013. - С. 8.

17. Магомедов Г.Б. Преступления небольшой и средней тяжести: освобождение от уголовной ответственности и от наказания: дис. ... канд. юрид. н.: 12.00.08. - М., 2015. - C. 65-77.

18. Сальгин Е.Н. Моделирование в праве: проблемы и перспективы // Право. Журнал Высшей школы экономики. - 2013. - № 3. - С. 12-31.

19. Об административном надзоре за лицами, освобожденными из мест лишения свободы: Федеральный закон от 06.04.2011 № 64-Ф3 [принят Гос. Думой 25.03.2011] (по сост. на 29.07.2017) // Рос. газ. - 2011. - 8 апр. 


\section{References}

1. Podrojkina I.A. Teoreticheskie osnovy postroenija sistemy nakazanij v ugolovnom zakonodatel'stve Rossii: dis. ... dokt. jurid. nauk: 12.00.08. - Omsk, 2017. - S. 66-110.

2. Miljukov S.F. Rossijskoe ugolovnoe zakonodatel'stvo: opyt kriticheskogo analiza. SPb.: Znanie, 2000. - S. 149-173.

3. Bochkarev S.A. Aksiologija ugolovnogo prava: vvedenie $\mathrm{v}$ temu i problemy ee stanovlenija // Rossijskij zhurnal pravovyh issledovanij. - 2015. - № 4. - S. 73-80.

4. Djad'kin D.S. Teoreticheskie osnovy naznachenija ugolovnogo nakazanija. - SPb.: Juridicheskij tsentr press, 2006. - S. 70-121.

5. Tagantsev N.S. Russkoe ugolovnoe pravo. Lektsii. Chast' obschaja. - M.: Nauka, 1994. - S. 100-102.

6. Poznyshev S.V. Osnovnye nachala nauki ugolovnogo prava. - M.: Spark, 1999. - S. 465-467.

7. Dujunov V.K. Ugolovno-pravovoe vozdejstvie: teorija i praktika. - M.: Norma, 2003. - S. 28.

8. Lopatin V.V., Lopatina L.E. Russkij tolkovyj slovar. - M.: Eksmo, 2007. - S. 78.

9. Lopashenko N.A. Osnovy ugolovno-pravovogo vozdejstvija: ugolovnoe pravo, ugolovnyj zakon, ugolovno-pravovaja politika. - SPb: Juridicheskij tsentr press, 2004. - S. 7.

10. Sabitov T.R. Ugolovno-pravovaja politika Rossijskoj Federatsii i ee printsipy // Vestnik NGU. Serija «Pravo». - 2007. - T. 3, Vyp. 1. - S. 167-175.

11. Voronin V.N. Individualizatsija nakazanija: monografija. - M.: Prospekt, 2017. S. $56-60$.

12. Bavsun M.V. Ugolovno-pravovoe vozdejstvie: ideologija, tseli i sredstva realizatsii: dis. ... dokt. jurid. nauk: 12.00.08. - Omsk, 2013. - S. 10-11.

13. Podrojkina I.A., Ulez'ko S.I. Sistema ugolovnyh nakazanij v ierarhii mer juridicheskoj otvetstvennosti // Vestnik Krasnodarskogo universiteta MVD Rossii. - 2016. № 2. - S. 40-44.

14. Gareev M.F. Zakonodatel'naja reglamentatsija mer ugolovno-pravovogo vozdejstvija - ujasnenie suschnosti ugolovnoj otvetstvennosti // Vestnik TISBI. - 2011. - № 3. S. 309-317.

15. Akutaev R.M. Ponjatie i sistema inyh mer ugolovno-pravovogo haraktera, ih otlichie ot nakazanija // Rossijskaja justitsija. - 2014. - № 4. - S. 44-48.

16. Brilliantov A.V. Osvobozhdenie ot ugolovnoj otvetstvennosti s uchetom obobschenija sudebnoj praktiki: nauchno-prakt. posobie. - M.: Prospekt, 2013. - S. 8.

17. Magomedov G.B. Prestuplenija nebol'shoj i srednej tjazhesti: osvobozhdenie ot ugolovnoj otvetstvennosti i ot nakazanija: dis. ... kand. jurid. n.: 12.00.08. - M., 2015. - S. 65-77.

18. Salygin E.N. Modelirovanie v prave: problemy i perspektivy // Pravo. Zhurnal Vysshej shkoly ekonomiki. - 2013. - № 3. - S. 12-31.

19. Ob administrativnom nadzore za litsami, osvobozhdennymi iz mest lishenija svobody: Feder. zakon ot 06.04.2011 № 64-FZ [prinjat Gos. Dumoj 25.03.2011] (po sost. na 29.07.2017) // Ros. gaz. - 2011. - 8 apr.

Поступила в редакцию 17 июня 2018 г. 
UDC 343.24

DOI: 10.21779/2500-1930-2018-33-3-112-117

\title{
To the question of hierarchy of measures of criminal-legal influence
}

\begin{abstract}
D.B. Laptev
The West Siberian Branch of the Russian State University of Justice; Russia, Tomsk, Lenin st., 2; Lapa612@mail.ru

The article is devoted to the hierarchy of measures of criminal law impact. The article reveals the "procedural" approach to the definition of criminal law impact, as well as its material and legal aspect, which includes a list of measures by which criminal law policy forms the direction of correction of criminal behavior. The necessity of withdrawal of exemption from criminal liability and punishment from the structure of criminal-legal impact is substantiated. Relate to the category of "criminal influence" and "criminal liability". The author of the article makes a conclusion according to which "criminal liability" is close in meaning but broader in content and covers a set of additional restrictions that apply to the person during the period when the main relationship associated with the coercion of a person to the obligation to suffer the negative consequences in connection with the crime. The approach to determination of hierarchy of measures of criminal-legal influence in which its subject, lawlimiting essence, rational economy of measures of the state coercion is reflected is offered: two rather independent, interpenetrating subsystems (punishment and other measures of criminal-legal character) in which separate elements are subordinated.
\end{abstract}

Keywords: criminally-legal influence, criminal responsibility, punishment, other measures of criminally-legal character, hierarchy of criminal law measures.

Received 17 June, 2018 